\title{
"AN EXCELLENT CORE": RUTGERS' MILTON COLLECTION
}

\section{BY FERNANDA H. PERRONE}

In creating this bibliography, I am indebted to Special Collections cataloger Silvana Notarmaso, who cataloged and re-cataloged the Milton Collection in conjunction with the 2011 exhibition, John Milton and the Cultures of Print. The information in the checklist was largely drawn from her careful research and knowledge of rare book description. I would also like to thank Thomas Fulton of the Rutgers Department of English for many helpful suggestions.

\section{$\underline{\text { Introduction }}$}

Special Collections and University Archives at Rutgers University Libraries is fortunate to hold a significant collection of early editions of works by John Milton. Numbering fifty-six books, it is the fifth-largest Milton collection at a public university in the United States. Originally known as Queen's College, Rutgers was chartered in 1766 as a small private institution affiliated with the Dutch Reformed Church. In the early records of the college, John Milton's name appears in 1782, when members of the Athenian Society, the student literary society that started Rutgers' first library, debated his work at one of their meetings. The work of the Society-and that of the college as a whole-was disrupted by the American Revolution, and no one knows what became of this fledging library.

By the early nineteenth century, the college had a small library chiefly consisting of theological works. Two new literary societies, the Peithessophian and the Philoclean were founded in 1825. These societies built their own libraries, which compared favorably to the college library and were focused on literature. When the societies declined in popularity in the late nineteenth century, their libraries were integrated into that of the college, forming the nucleus of the current library. Indeed, the 1821 edition of the Poetical Works of John Milton bears the stamp of the Peithessophian Society. Unfortunately, early library accession records are incomplete, but apparently 
the library began collecting rare books seriously in the 1930s. In 1937, the Associated Friends of the Library of Rutgers University was founded to encourage gifts of books and manuscripts and raise funds for special needs. The Journal of the Rutgers University Libraries, founded in the same year, included a regular column on notable acquisitions, as well as scholarly articles based on the library's holdings. The Milton collection grew gradually through donations and judicious purchases. Some of these acquisitions were shepherded by J. Milton French, Milton scholar and chair of the Rutgers English Department.

Joseph Milton French was born in Randolph, Massachusetts, in 1895 (see Figure 4.1). He received a B.A. from Harvard in 1917. After serving in the American Expeditionary Force during the First World War, he returned to Harvard, where he studied with the sixteenth- and seventeenth-century specialist Hyder E. Rollins, receiving a Ph.D. in 1928. French taught at Lafayette College, New York University, Dartmouth, Harvard, University of Akron, and Queens College before coming to Rutgers in January 1940. As Kathryn James's essay in this volume vividly illustrates, the Second World War had an extraordinarily impact on academic life, and French committed himself, as department chair, to building up the faculty and graduate programs that had languished during the war. The English department's offerings increased from two graduate courses with three or four students to thirteen courses and nearly one hundred graduate students by French's retirement in 1960. J. Milton French died in 1962, leaving a wife, Elva Plunkett, two children, David P. French and Jane Lumley, and several grandchildren. His son, who also studied with Hyder Rollins, became a professor of eighteenth-century English literature at the University of Oklahoma.

In 1930, J. Milton French began working on his what became his life's work, the five-volume Life Records of John Milton, published by the Rutgers University Press from 1949 to 1958. In addition to his monograph Milton in Chancery (1939), French worked on several other landmark multivolume works. He was contributing editor of The Works of John Milton, published from 1931 to 1938 by Columbia University Press, and served on the editorial board of The Complete Prose Works of John Milton. French was selected as an Honored Scholar by the Milton Society of America in 1956. French seems to have begun working with Rutgers Librarian George Osborn on acquiring books for Rutgers almost immediately 


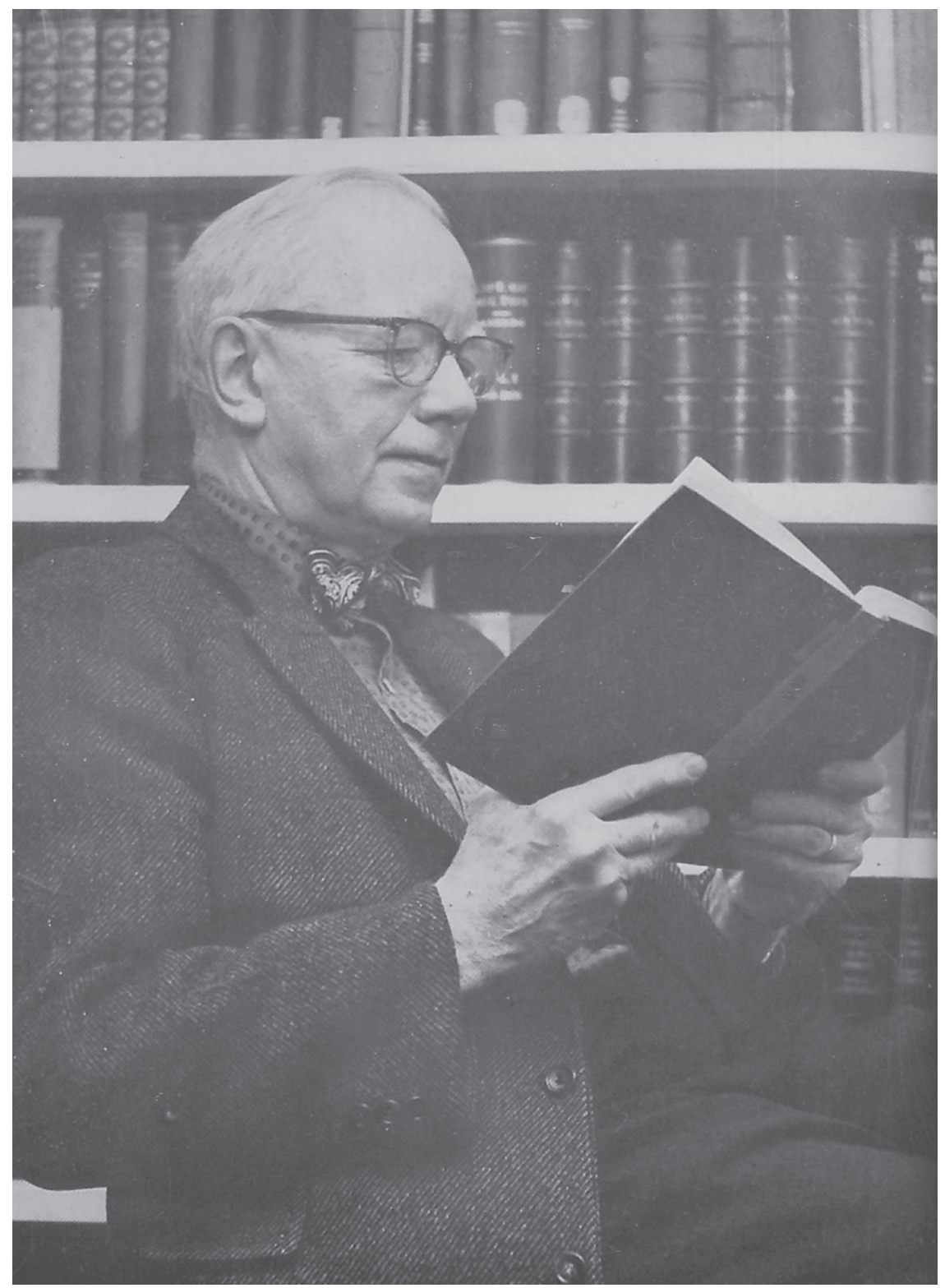

4.1 J. Milton French, frontispiece, Essays in Literary History. ed. by Rudolf Kirk and C.F. Main. (New Brunswick, NJ: Rutgers University Press, 1960). Photo by David P. French. 
upon his arrival in New Brunswick. (George has no relation to the scholar-curator James Marshall Osborn at Yale, whom he also worked with, as Kathryn James discusses in her essay.) In a 1940 article in The Journal of the Rutgers University Libraries, French writes,

Since last February we have acquired original editions of three of Milton's divorce tracts (The Doctrine and Discipline of Divorce of 1644, Tetrachordon of 1645, and Colasterion of 1645), three political works (the Defensio of 1651, a later edition of the same work of 1692, and Eikonoklastes of 1649), and several other books (An Apology of 1642, The History of Britain of 1670, and the Letters of State of 1694). Among various useful companion books in this field which have been added are the rare index to Masson's Life, Aldis Wright's fine facsimile of Milton's Cambridge Manuscript, and Helen Darbishire's recent facsimile of the manuscript of Book I of Paradise Lost. With the Columbia set of Milton and other editions and critical works which we already have, these give us an excellent core of a working Miltonic library. ${ }^{1}$

1940 was obviously an extraordinary year for collecting Miltonia. We unfortunately lack the sort of precision reported in this article for the exact dates of acquisition for much of the collection, or just where the funds for this ambitious rate of acquisition came from-though such works were a great deal less expensive than they are now. It is possible that French donated some of these works himself or contributed funds for their purchase. We do know that they were obtained from a book dealer, Barnet J. Beyer of New York, whose bookseller descriptions have been tipped into each volume. In fact, in 1941, both French and Beyer are listed as having made gifts to the library. ${ }^{2}$ Tetrachordon also bears a Rutgers Library bookplate stating that it was given by Albert Stanburrough Cook. Cook was a Rutgers graduate of the class of 1872, who became the Chair of the English department at Yale, which he joined in 1889 after teaching at the University of California. After a highly influential and prolific career in the early years of English as an academic discipline, Cook died in 1927, a bit too early to be part of French's scholarly and professional network. 
Little is known about the provenance of the other early Milton editions in Rutgers' collection. Several titles were received as gifts from alumni, faculty members, or others whose identities could not be determined. Our excellent copies of Areopagitica (1644) and The Doctrine and Discipline of Divorce (1643) were given by New Jersey resident Ogden White in $1954 .{ }^{3}$ This information has been noted on the checklist when available.

While I have tried to include standard bibliographical information on each book in the checklist, additional details can be gleaned through searching the Rutgers University Libraries public online catalog. The books have been arranged chronologically by year, and alphabetically within years, with a few logical exceptions. Titles have been transcribed as they appear on the title page, with the addition of some marks of punctuation to render them more readable. Question marks have been inserted where information was deduced from other sources, or, in case of handwriting, was not completely legible.

\section{Checklist}

An apology against a pamphlet call'd A Modest confutation of the animadversions upon a remonstrant against Smectymnuus. London: Printed by E.G. [i.e. Edward Griffin] for Iohn Rothwell, and are to be sold at the signe of the Sunne in Pauls Church-yard, 1642. [4], 58, [1] p.; $19 \mathrm{~cm}$ (4to).

A reply to: Hall, Joseph. A modest confutation of a slanderous and scurrilous libell. This is the fifth of Milton's pamphlets written in support of the five Protestant ministers in the Smectymnuus controversy. Smectymnuus is a pseudonym composed of the initials of the authors who used it, viz. Stephen Marshall, Edmund Calamy, Thomas Young, Matthew Newcomen, and William Spurstowe.

Wing 2090

ESTC R12880

Bookseller description from Barnet J. Beyer tipped in.

The doctrine and discipline of divorce, restor'd to the good of both sexes, from the bondage of canon law, and other mistakes, to Christian freedom, guided by the rule of charity, wherein also many places of Scripture, have recover'd their long-lost meaning, seasonable to be now thought on in the reformation intended. London: Printed by T.P. [i.e. Thomas Paine] and M.S. [i.e. Matthew Simmons] in Goldsmiths Alley, 1643. [2], 
48, [2] p.; $19 \mathrm{~cm}$ (4to).

Wing (1996 ed.) M2108

ESTC R12932

Presented by Ogden White

Acquired in 1954

Areopagitica: a speech by Mr. John Milton for the liberty of unlicenc'd printing, to the Parlament of England. London: [n.p.], printed in the yeare, 1644. [2], 40, [2] p.; $19 \mathrm{~cm}$ (4to).

First edition, $2^{\text {nd }}$ state.

Special Collections copy imperfect: Last blank leaf wanting; head margins closely cropped, all page numbers and first line of text on some pages cut into.

Special Collections copy bound with A nevv invention, or, A paire of cristall spectacles [London]: Printed according to order for G. Bishop, 1644; and Milton, John. Brief notes upon a late sermon, titl'd, The fear of God and the King. London: [n.p], 1660.

Wing M2092

ESTC R210022

Presented by Ogden White.

Acquired in 1954

The doctrine \& discipline of divorce, restor'd to the good of both sexes, from the bondage of canon law, and other mistakes, to the true meaning of Scripture in the law and gospel compar'd, wherein also are set down the bad consequences of abolishing or condemning of sin, that which the law of God allows, and Christ abolisht not, now the second time revised and much augmented, into books, to the Parliament of England, with the Assembly, the author J. M. London: [Thomas Payne(?) and Matthew Simmons], imprinted in the yeare 1644. [8], 82 p.; $19 \mathrm{~cm}$ (4to). Wing M2109

ESTC 11274

Bookplate of John Camp Williams.

Acquired 1940 upon advice of J. Milton French.

The judgement of Martin Bucer, concerning divorce, writt'n to Edward the sixt, in his second book of the kingdom of Christ, and now Englisht, wherin a late book restoring the Doctrine and discipline of divorce, is heer confirm'd and justify'd by the authoritie of Martin Bucer, to the Parlament of England, publish by authoritie. London: Printed by Matthew Simmons, 1644. [16], 24, [2] p.; 19 cm (4to). 
Translation of "De coniugio et divortio" from "De regno Christi" by Bucer, in support of "The doctrine and discipline of divorce" by Milton.

Includes post-script.

Wing B5270

ESTC R3964

Colasterion, a reply to a nameless ansvver against The doctrine and discipline of divorce, wherein the trivial author of that answer is discover'd, the licencer conferr'd with, and the opinion which they traduce defended, by the former author, J. M. [London: Matthew Simmons], printed in the year, 1645. [4], 27, [1] p.; $19 \mathrm{~cm}$ (4to).

Wing 2099

ESTC R212205

Bookseller description from Barnet J. Beyer tipped in. Acquired 1940 on advice of J. Milton French.

Tetrachordon, expositions upon the foure chief places in Scripture, which treat of mariage, or nullities in mariage ... wherin The doctrine and discipline of divorce, as was lately publish'd, is confirm'd by explanation of Scripture, by testimony of ancient fathers, of civill lawes in the primitive church, of famousest reformed divines, and lastly, by an intended act of the Parlament and Church of England in the last yeare of Edvvard the Sixth, by the former author J. M. London: [n.p.], printed in the yeare 1645.

[8], 40, 37-98, [2] p.; $20 \mathrm{~cm}$ (4to).

Printed by Thomas Payne and Matthew Simmons.

Coleridge identifies 3 states of signature A.

Special Collections copy: Coleridge state 2, all errors corrected except A2, line 16 "perswaston"; last blank wanting.

Wing M2184

ESTC R212199

Bookseller description of Barnet J. Beyer tipped in. Presented by Professor Albert Stanburrough Cook. ${ }^{4}$

Eikonoklastēs in answer to a book intitl'd Eikōn basilikē, the portrature of his Sacred Majesty in his solitudes and sufferings, the author I.M.; published by authority. London: Printed by Matthew Simmons, next dore to the gilded Lyon in Aldersgate street, 1649. [14], 242 p.; 19 $\mathrm{cm}$ (4to).

A reply to Gauden, John. Eikōn basilikē. Authorship of Eikōn basilikē 
was originally attributed to Charles I, but according to Madan (pp. 126-133), it was written by John Gauden who probably included some authentic writings of the King.

Special Collections copy has armorial bookplate of Thomas Brooke, F.S.A., Armitage Bridge.

Bookseller's description from Barnet J. Beyer tipped in.

Wing (1996 ed.) M2112

ESTC R202156

Acquired 1940 on advice of J. Milton French.

\section{EIKONOKAA $\Sigma T H \Sigma$}

I $N$

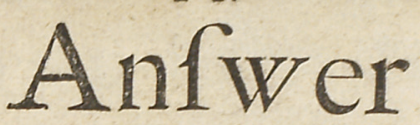

To a Book Intitl'd

$E^{\prime} I K \Omega^{\prime} N B A \Sigma I \Lambda I K H_{\text {, }}$

T H E

Portratire of his Sacred M a je s ty

in his Solitudes and Sufferings.

The Author I. $M$.

P R O V. 28. I5, I6, I7.

15. As a roaring $L y o n$, and a ranging Beare, $\int 0$ is a wicked $R u$ ler over the poor people.

16. The Prince that poanteth underffanding, is alfo a great oppreffor; but be that bateth covetonfne $\int e$ Thall prolong bis dayes.

17. A mas that doth violence to the blood of any perfon, ball fly to the pit, let no man ftay bim.

\section{Saluft. Comjwrat, Gatilin.}

Regium imperum, quod initio, confervandx libertatis, atque augenda reipub. causâ fuerat, in fuperbiam, dominationemque fe convertit. Regibus boni, quam mali, fuffectiores funt; femperque his aliena virtus for-
midolola eft.

Quidlibetimpunè facere, hoc fcilicet regium eft.

\section{Publifbed by Autbority.}

London, printed by Mattben Simmons, next dore to the gilded Lyon in Aldsrigate firect. $\quad 16+9$. 
The grand case of conscience concerning the engagement stated \& resolved, or, A strict survey of the Solemn league \& Covenant in reference to the present engagement. London: Printed by John Macock for Francis Tyton, and are to be sold at his shop at the three Daggers neer the Inner Temple, Fleetstreet, 1650. 22, [2]p.; $19 \mathrm{~cm}$ (4to). ESTC 206308 Formerly attributed to John Milton.

Joannis Miltoni Angli Pro populo Anglicano defensio, contra Claudii anonymi, aliàs Salmasii, defensionem regiam. Londini: Typis DuGardianis, ann Domini 1651. [22], 205, [1] p.; 19 cm (4to). First edition, third issue (with errata leaf).

Title vignette: Arms of the Commonwealth of England. In the third issue the title page vignette is a square metal block of the Commonwealth Arms instead of a round woodcut found in the first issue, and the initial blank of the first two issues "is folded round, so as to follow the title-page, and has on the recto seven lines of errata, with a publisher's note asking the reader to correct minor defects."

M2166

ESTC R32430

Bookseller description of Barnet J. Beyer tipped in.

Leather bookplate of John Camp Williams.

This copy may be the one acquired in 1940 on the advice of J. Milton French.

Ioannis Miltoni Angli Pro populo Anglicano defensio, contra Claudii anonymi, aliàs Salmasii, defensionem regiam. Londini [i.e. Amsterdam]: Typis Du Gardianis [i.e. Louis Elzevier], anno Domini 1651. 283. [5] p.; $14 \mathrm{~cm}$ (12mo).

The imprint is false. Actually printed in Amsterdam by Louis Elzevier.

Title vignette: Arms of the Commonwealth of England. Wing (1996 ed.) M2168C

ESTC R40028

Special Collections copy 1: Contemporary vellum over boards; ms. title on spine: Miltoni Defensio pop. Angl. co[ntra] [Salmasius]; bookseller description tipped in.

Special Collections copy 2: Contemporary vellum over boards; ms. titles, printer name on spine, ms. notes in French on front free endpaper. 
Special Collections copy 2 bound with: Rowland, John. Pro rege et populo Anglicano apologia. Antuerpiae: Apud Hieronymum Verdussen, 1651.

Ioannis Miltoni Angli Pro populo Anglicano defensio, contra Claudii anonymi, aliàs Salmasii, defensionem regiam. Londini [i.e. Utrecht?]: Typis Du-Gardianis, anno Domini 1651. [20], 244 p.; $13 \mathrm{~cm}$ (12mo).

Title vignette: Arms of the Commonwealth of England The imprint is false. One of seven duodecimo continental reprints, probably printed at Utrecht. Actual printer's name unknown. Wing ( ${ }^{\text {nd }}$ ed.) M2168D

ESTC R31234

Special Collections copy: Contemporary vellum over boards with double gilt fillet border; and two pin (upper board) and strap/clasp (lower board) fastenings.

Acquired with the Ralph G. Wright Book Fund, which was established in 1937.

Ioannis Miltoni Angli Pro populo Anglicano defensio, contra Claudii anonymi, aliàs Salmasii, defensionem regiam: cum indice. Londini [i.e. Amsterdam]: Typis Du-Gardianis, anno Domini 1651. 260, [12] p.; $14 \mathrm{~cm}(12 \mathrm{mo})$.

Title vignette: Arms of the Commonwealth of England.

The imprint is false. Actually printed in Amsterdam by Louis

Elzevier.

Includes index.

Wing (1996 ed.) M2168B

ESTC R21409

Ioannis Miltoni Angli Pro populo Anglicano defensio, contra Claudii anonymi, aliàs Salmasii, defensionem regiam. Londini [i.e. Gouda?]: Typis Du Gardianis [i.e. G. de Hoeve?], anno Domini 1652. 192 p.; $14 \mathrm{~cm}$ (12mo).

A reply to Saumaise, Claude. Defensio regia pro Carolo I.

The imprint is false. Possibly printed in Gouda by G. de Hoeve.

Title vignette: Arms of the Commonwealth of England.

Wing (1996 ed.) M2169

ESTC R18974

Cut-out bookseller listing for Milton's Pro populo Anglicano defensio affixed to front pastedown. 
Special Collections copy 2: Bound with: Saumaise, Claude. Defensio regia, pro Carolo I. [Leiden?]: Sumptibus Regiis, 1649.

Special Collections copy 2: Ink stamp of Sir Robert Harry Inglis (1786-1855), British Conservative politician.

Joannis Miltoni Angli Pro populo Anglicano defensio, contra Claudii anonymi, aliàs Salmasii, defensionem regiam. Londini [i.e. Utrecht]: Typis Du Gardianis [i.e. Theodorus ab Ackersdijck and Gisbertus à Zijll], anno Domini 1652. 276, [12] p.; $13 \mathrm{~cm}$ (12mo).

The imprint is false. Actually printed in Utrecht by Theodorum ab Ackersdijck and Gisbertus à Zijll.

Page 248 misnumbered 148.

Title vignette: Arms of the Commonwealth of England.

Wing (1996 ed.) M2169A

ESTC R31897

Special Collections copy 1: Contemporary vellum over boards with double blind fillet border (ties lacking).

Special collections copy 1: Manuscript note indicating that Milton had been released from prison in contemporary hand on rear flyleaf.

Acquired in 1967.

Joannis Miltoni Angli Pro populo Anglicano defensio secunda, contra infamen libellum anonymum cui titulus, Regii sanguinis clamor ad coelum adversus parricidas anglicanos. Londini: Typis Neucomianis, 1654. [2], 173, [3] p; $15 \mathrm{~cm}$ (8vo).

A reply to the tract by Pierre Du Moulin, which Milton had mistakenly attributed to Alexander More, its editor.

Wing 171

ESTC R208486

Joannis Miltoni Defensio secunda pro populo Anglicano, contra infamen libellum anonymum, cujus titulus, Regii sanguinis clamor adversus parricidas anglicanos, accessit Alexandri Mori, Ecclesiastae sacrarumque litterarum professoris, Fides publica contra calumnias Ioannis MiltonI scurrae. Hagae-Comitum: Ex typographia Adriani Vlacq, MDCLIV [1654] [16], 128 p.; $13 \mathrm{~cm}$ (12mo).

"Lectori" (pref.) signed: Georgius Crantzius S.S. Theol. D. 


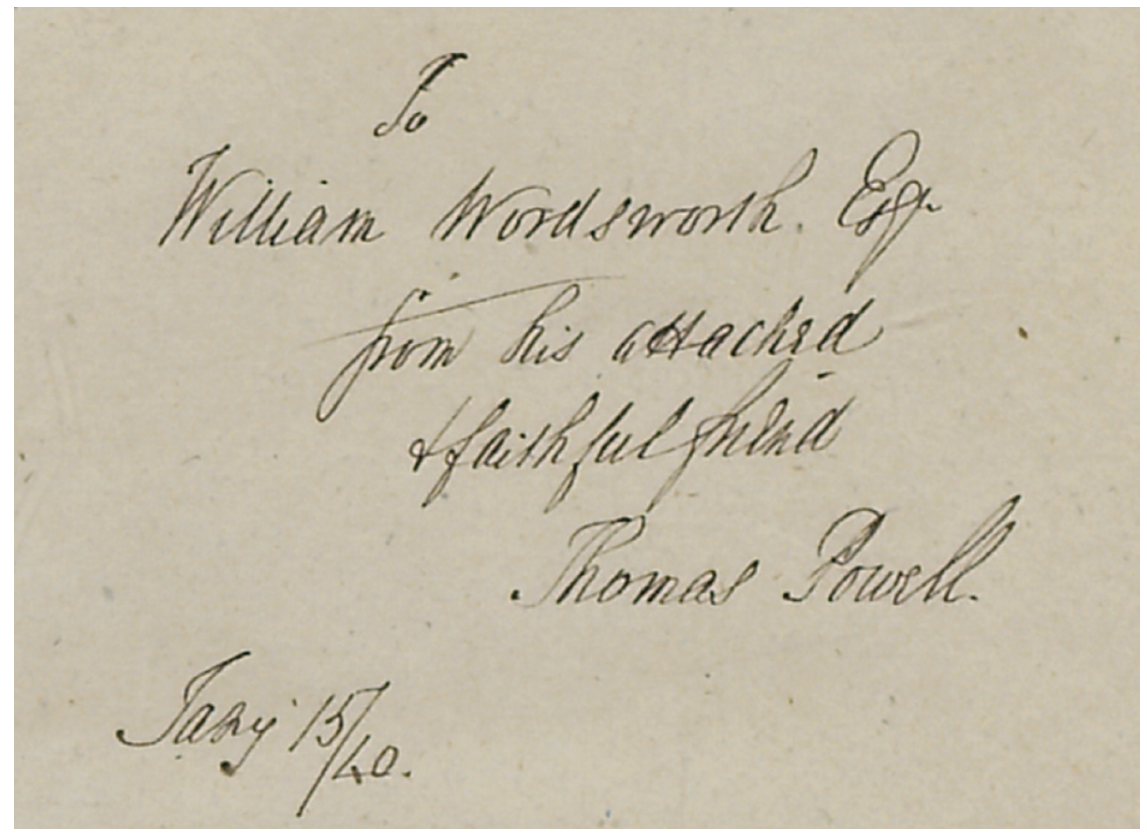

4.2 Inscription from John Milton, Paradise Lost, 1669.

First issued in London, also in 1654, under the title: Pro populo anglicano defensio secunda.

Special Collections copy without [ $2^{\text {nd }}$ pt.] More's Fides Publica contra calumnias Ioannis Miltoni.

Not in ESTC.

Joannis Miltoni Angli Pro se defensio contra Alexandrum Morum ecclesiasten, libelli famosi, cui titulus, Regii sanguinis clamor ad coelum adversùs parricidas Anglicanos, authorem rectè dictum. Londini: Typis Neucomianis, 1655. [4], 204 p.; 15 cm (8vo).

Milton's final reply to More's Fides publica.

ESTC R209019.

Special Collections copy: First blank leaf wanting.

Paradise lost: a poem in ten books / the author John Milton. London: Printed by S. Simmons, and are to be sold by T. Helder at the Angel in Little Brittain, 1669. [356] p.; 19 cm (4to).

The fifth state of the first edition title page, sometimes called the 7th.

Wing (1996 ed.) M2142

ESTC R13406 
Special Collections copy: Upper right corner of title page torn away, affecting the "t." in "lost.", repaired, with "t." supplied in ms. Inscribed on front free endpaper: "To William Wordsworth Esq., from his attached \& faithful friend, Thomas Powell, Jan[ua]ry $15 / 40^{\prime \prime}$

Autograph on title page (defaced, affecting legibility): Henry [?] Leech; inscription and autograph (title page verso) of Jonathan Adams; monogram bookplate [of William Wardlaw Waddell]: "WWW" with motto "Orna verum." Waddell was a classical Greek scholar at the University of Glasgow.

Presented by Rutgers College Class of 1936.

The history of Britain, that part especially now call' England from the first traditional beginning, continu'd to the Norman Conquest, collected out of the antientest and best authours thereof by John Milton. London: Printed by J.M [i.e. John Macock] for J. Allestry, at the Rose and Crown in St. Paul's Church-Yard, MDCLXX [1670] [4], 308, [56] p.; $21 \mathrm{~cm}$ (4to).

Frontispiece portrait signed: Gul. Faithorne ad vivum delin. et sculpsit.

Includes index. With a final errata leaf.

Wing 2119

ESTC R13663

Ownership inscriptions/autographs of Judeth Piggott, T.F., Silas Cook, Judeth Hyde and Anne Vivian.

Acquired 1940 on the advice of J. Milton French.

Joannis Miltoni Angli, Artis logicae plenior institution ad Petri Rami methodum concinnata adjecta est Praxis annalytica \& Petri Rami vita, libris duobus. Londini: Impensis Spencer Hickman, Societatis Regalis Typographi, ad insigne rosae in Cemeterio, D. Pauli, 1672. [20], 223 [i.e. 228] p.; $15 \mathrm{~cm}$ (12mo).

Engraved portrait: W Dolle sculpsit.

ESTC R3322

Joannis Miltonii Angli, Epistolarum familiarium liber unus, quibus accesserunt, ejusdem, jam olim in collegio adolescentis, prolusiones quaedam oratoriae. Londini: Impensis Brabazoni Aylmeri sub the signo Trium Columbarum, via vulgo Cornhill dicta, an.Dom 1674. 155, [5] p.; $16 \mathrm{~cm}$ (8vo).

Wing 2117 
ESTC R13511

Special Collections copy: First and last blank leaves and advertisement leaf at end wanting.

Paradise lost: a poem in twelve books, the author John Milton. The second edition revised and augmented by the same author. London: Printed by S. Simmons next door to the Golden Lion in AldersgateStreet, 1674. [8], 333, [3]p.; $18 \mathrm{~cm}$ (8vo).

Many copies of this edition include a copy of the Dolle engraving of the Faithorne portrait as a frontispiece.

ESTC R13351

Special Collections copy imperfect: Leaves A3 (bearing Andrew Marvell's poem "On Paradise lost") and Y8 (final blank) wanting; without frontispiece portrait (as issued?).

Literae pseudo-senatûs Anglicani, Cromwellii, reliquorumque perduellium nomine ac jussu conscriptae, a Joanne Miltono. [Amsterdam: By Pieter and Willem Blaeu for Moses Pitt, London?], impressae anno 1676. [4], 234, [6] p.; $14 \mathrm{~cm}$ (12mo).

A surreptitious publication of dispatches written by Milton in his capacity of Latin Secretary to the Council of State, between the years 1649 and 1659.

ESTC R16771.

Special Collections copy: Contemporary vellum over boards; red sprinkled edges.

The history of Britain, that part especially now call'd England, from the first traditional beginning continu'd to the Norman Conquest, collected out of the antientest and best authours thereof by John Milton. London: Printed by J.M [i.e. John Macock] for John Martyn at the sign of the Bell in St Paul's Church-Yard, MDCLXXVII [1677] 357, [59] p.; 18 cm (8vo).

This is the first issue of the second edition.

Wing M2121

ESTC R16523

Special Collections copy: Contemporary panelled calf(?) with blind tooled corner fleurons, red stained edges.

Special Collections copy bound with: Burnet, Gilbert. Some passages of the life and death of the Right Honourable John, Earl of Rochester.

London: Printed for Richard Chiswel, 1680. 
The history of Britain, that part especially now call'd England from the first traditional beginning, continu'd to the Norman Conquest, collected out of the antientest and best authours thereof by John Milton, $2 \mathrm{~d}$ ed. London: Printed by J.M [i.e. John Macock] for Mark Pardoe, and are to be sold at the Black Raven over against Bedford-House, in the Strand, 1678. [2], 5-357, [59] p.; $18 \mathrm{~cm}$ (8vo).

Includes index.

Wing 2122

ESTC R32429

Autograph of Charles Augustus West, Esq., 1785.

Paradise lost: a poem in twelve books, the author John Milton. The third edition revised and augmented by the same author. London: Printed by S. Simmons next door to the Golden Lion in AldersgateStreet, 1678. [8], 331, [5]p.; $18 \mathrm{~cm}$ (8vo).

Special Collections copy includes Dolle engraving of the Faithorne portrait as frontispiece.

Wing 2145

ESTC R19396

Autograph L. J. Papillon.

Paradise regain'd: a poem in IV books, to which is added Samson Agonistes, the author John Milton. London: Printed by John Starkey at the Mitre in Fleet-Street, near Temple-Bar, MDCLXXX [1680] 132, [4] p.; $18 \mathrm{~cm}$ (8vo).

License to print.

Wing (2 ${ }^{\text {nd }}$ ed.) M2153

Special Collections copy imperfect: last leaf of advertisements wanting.

Paradise lost: a poem in twelve books, the authour John Milton. The fourth edition, adorn'd with sculptures. London: Printed by Miles Flesher, for Richard Bently, at the Post-Office in Russell-street, and Jacob Tonson at the Judge's-Head in Chancery-lane near Fleet-street, MDCLXXXVIII [1688] [4], 219, [1], 219-250, 151-197, 298-343, [7] p., [13] leaves of plates; $33 \mathrm{~cm}$ (folio).

Frontispiece, portrait of the author signed R. White sculp.; other plates engraved by M. Burghers or P.P. Bouche after J.B. Medina and Bernard Lens, Sen.

One of three imprint variants of this edition.

Issued on ordinary paper (double inner margin measures $65 \mathrm{~mm}$., predominantly with foolscap watermark) and on large paper 
(double inner margin measures $85 \mathrm{~mm}$., with grapes, or arms of France and Navarre watermarks).

"The names of the nobility and gentry that encourag'd, by subscription, the printing of this edition of Milton's Paradise Lost," at end.

Wing ( $2^{\text {nd }}$ ed.) M2146

ESTC R13313

Special Collections copy: issue on ordinary paper.

Special Collections copy: Autograph St. And. Thornhagh

(1674-1742), non-conformist and M.P., Nottinghamshire.

Eikonoklastēs in answer to a book intitul'd Eikon basilikē, the portracture of his Sacred Majesty King Charles the First in his solitudes and sufferings, by John Milton. Amsterdam: [n.p.], printed in the year, 1690. [16], 207, [1] p.; $19 \mathrm{~cm}$ (8vo).

Wing (1996 ed.) M2115

ESTC R13974

A defence of the people of England, by John Milton, in answer to Salmasius's Defence of the king. Translation, by Joseph Washington, of Pro populo Anglicano defensio. [Amsterdam?: n.p.], printed in the year 1692. [8], xxii, [2], 246, [2] p.; $18 \mathrm{~cm}$ (8vo).

"An advertisement to the reader" at end.

Wing ( $\left.2^{\text {nd }} e d.\right) 2104$

ESTC R9447

Acquired 1940 upon the advice of J. Milton French.

Special Collections copy: Contemporary panelled sprinkled calf(?) with blind tooled corner fleurons, rebacked; red lettering piece; red sprinkled edges.

Letters of state, written by Mr. John Milton, to most of the sovereign princes and republicks of Europe, from the year 1649, till the year 1659; to which is added, an account of his life, together with several of his poems, and a catalogue of his works, never before printed. London: [n.p.], printed in the year, 1694. [6], xlvii, [6], 336 p.; $16 \mathrm{~cm}$ (12mo).

A translation, by Edward Phillips of Literae pseudo-senatûs Anglicani, Cromwellii....

"The life of Mr. John Milton," was written by Edward Phillips.

Wing 2126

ESTC R4807 
Acquired 1940 upon advice of J. Milton French.

Paradise regain'd: a poem in four books, to which is added Samson Agonistes, and Poems upon several occasions, compos'd at several times, the author John Milton. The fifth edition. London: Printed for Jacob Tonson, within Grays-Inn Gate next Grays-Inn lane, 1707. [2], 457, [5] p.; $20 \mathrm{~cm}$ (8vo).

ESTC T134615

Paradise lost: a poem in twelve books, John Milton, the author: to which is prefix'd an account of his life. London: Printed for a Company of Stationers, MDCCXXXIX [1739] 317, [42] p., [14] leaves of plates (1 folded); $17 \mathrm{~cm}$ (12mo).

"The life of Mr. John Milton" is by Elijah Fenton.

Most plates engraved by John Lightbody; frontispiece plate signed Jacobus Smith.

Title in red and black.

ESTC T133921

Special Collections copy bound with: Addison, Joseph. Notes upon the twelve books of Milton's Paradise Lost. London: Printed for a Company of Stationers, [1739?]

Comus: a masque, (now adapted to stage) as alter'd from Milton's masque at Ludlow-castle, which was first represented on MichaelmasDay, 1634, before the Right Honourable the Earl of Bridgewater, Lord President of Wales ...; the music was composed by Mr. Hen. Lawes, who represented the attendant spirit. London: Printed for A. Millar, opposite to Katharine-Street, in the Strand, MDCCL [1750] 58, [2] p.; $21 \mathrm{~cm}$ (8vo).

ESTC T31078

Special Collections copy imperfect: Final advertisement leaf wanting.

Paradise lost: a poem in twelve books, the author John Milton, from the text of Thomas Newton, D.D. Birmingham: Printed by John Baskerville, for J. and R. Tonson, in London, MDCCLVIII [1758] [32], lxix, [1], 416 p.; $23 \mathrm{~cm}$ (8vo).

ESTC T133903

Special Collections copy: Contemporary calf with gilt pineapple/ dog-tooth roll border; rebacked in red sheep; gold tooled spine in six compartments, lettered direct; inscriptions: "The gift of the Earl of Exeter, 1755," "Autograph of my dearest and most venerable 
father (T. Rennell, Dean of Winton, 1825); For Charlie and Augusta, with my love and best wishes for many years of abiding happiness, always fondly, Kate."

Paradise regain'd: a poem in four books, to which is added Samson Agonistes, and Poems upon several occasions, the author John Milton, from the text of Thomas Newton, D.D. Birmingham: Printed by John Baskerville for F. and R. Tonson in London, MDCCLVIII [1758] [2], lxix, [4], 6-100, 102-163, [3], 166-390 p.; 22 cm (8vo). ESTC T134224

Special Collections copy imperfect: xlxix preliminary pages containing "The life of Milton" wanting.

Special Collections copy with subscribers' list (18 p.) and two poems on Paradise Lost by Samuel Barrow and Andrew Marvell bound in after title page.

Special Collections copy contemporary calf with single gilt fillet border; book plate of Robert Williams.

Paradise lost: a poem in twelve books, the author John Milton, from the text of Thomas Newton, D.D. Birmingham: Printed by John Baskerville, for J. and R. Tonson, in London, MDCCLIX [1759] [8], lxxii, 416 p., [1] leaf of plates, portrait; $24 \mathrm{~cm}$ (4to).

Frontispiece portrait by J. Miller often bound in.

No punctuation after "Birmingham" in imprint. Variant title page in some copies has a colon after "Birmingham".

ESTC T133905

Paradise regain'd: a poem in four books, to which is added Samson Agonistes, and Poems upon several occasions, the author John Milton, with notes of various authors by Thomas Newton, D.D. 2 vols. London: Printed for J. and R. Tonson, T. Caslon, T. Longman ... [and 6 others], MDCCLXVI [1766]

2 v.: portrait; $22 \mathrm{~cm}$ (8vo).

ESTC N19462

Presented by Professor Albert Stanburrough Cook.

Comus: a masque, as it is acted at the Theatres-Royal in Drury-Lane and Covent-Garden, altered from Milton. London: Printed for J. Wenman, no 144, Fleet-Street, and sold by all other booksellers in town and country, MDCCLXXVII [1777] 12 p., [1] leaf of plates, ill.; $22 \mathrm{~cm}$ (8vo). 
Adaptation by John Dalton.

ESTC T31076

Poems upon several occasions, English, Italian, and Latin, with translations by John Milton ...; with notes and explanatory, and other illustrations, by Thomas Warton ... London: Printed for James Dodsley, in Pall Mall, MDCCLXXXV [1785] xxviii, 620 p.; $23 \mathrm{~cm}$ (8vo).

ESTC T134607

Poems upon several occasions, English, Italian, and Latin, with translations by John Milton ...; with notes and explanatory, and other illustrations, by Thomas Warton, B.D. ... The second edition, with many alterations, and large additions. London: Printed for G.G.J. and J. Robinson, Pater-Noster Row, MDCCXCI [1791] xlvi, [2], 608 p.; $22 \mathrm{~cm}$ (8vo).

Appendix containing Remarks on the Greek verses of Milton by Charles Burney.

ESTC T2380

Special Collections copy: Contemporary sprinkled calf with gilt decorative roll border on sides. Armorial bookplate of William Howley, Archbishop of Canterbury.

Paradise lost by John Milton, with notes selected from Newton and others, to which is prefixed the life of the author, with a critical dissertation on the poetical works of Milton and observations on his language and versification by Samuel Johnson, L.L.D. 2 vols. London Printed for J. Parsons, 21, Paternoster Row, 1796. ill., port.; 25 cm (8vo).

Engraved title pages. Title page for v. 2 is same title page used for v. 1 (reads "Vol. 1").

With a list of subscribers in v. 1.

ESTC 134624

Special Collections copy (v. 1-2): Contemporary tree calf (or sheep).

Comus / masque de Milton, représenté au Chateau de Ludlow, en 1634, devant John Egerton, comte de Bridgewater. A Paris: De l'Imprimerie de Charles Crapelet ..., 1806. xiii, [3], 87, [1] p.; $31 \mathrm{~cm}$.

Edited by Francis Henry Egerton, Earl of Bridgewater; translation into French by De La Bintinaye and into Italian by Gaetano Polidori.

Added title page in Italian; text in French and Italian on opposite pages. 
The state of innocence, and the fall of man, described in Milton's Paradise lost, rendered into prose, with historical, philosophical, and explanatory notes, from the French of the learned R. de St. Maur, by a gentleman of Oxford. Trenton: Published by William Robinson, and John C. Moore, 1813 ([Trenton: William and David Robinson, printers.) viii, [2] 12-450 p., [1] leaf of plates, portrait; $22 \mathrm{~cm}$.

Translation and paraphrase by George Smith Green of Dupré de Saint-Maur's French Paradise lost translation Paradis perdu de Milton. Ownership inscription of Ambrose Kitchel.

The Poetical works of John Milton, with the life of the author, in two volumes. 2 vols. Philadelphia: Published by John Stevenson, 1821 ([Philadelphia]: Anderson \& Meehan, printers).

Frontispieces signed C. Tiebout, sc. An additional plate in v. 1 is engraved by Kneass, Young \& Co. after a painting by Henry Fuseli. Vol. 1: xiii, [6], 20-267, [1] p., [2] leaves of plates; v. 2: 282 p., [1] leaf of plates.

Special Collections copy imperfect: second plate in v. 1 and frontispiece plate in $\mathrm{v}$. 2 wanting; upper portion of title page in $\mathrm{v} .1$ torn away, affecting "The poetical" in title.

Special Collections v. 1 gift inscription from Christopher Hunt (?) to the Peithossophian Society (of Rutgers College). V. 1 and v. 2 ink stamp of the Rutgers College Peithossophian Society Library.

Joannis Miltoni Angli De doctrina Christiana libri duo posthumi quos ex schedis manuscriptis deprompsit, et typis mandari primus curavit Carolus Ricardus Sumner, A.M. Bibliothecae Regiae praefectus. Cantabrigiae: Typis Academicis, excudit Joannes Smith, academiae typographus Veneunt Londini apud Knight, Budd et Calkin, Ebers ... [and 4 others], MDCCCXXV [1825] viii, 544, [2] p., [2] leaves of plates; 30 $\mathrm{cm}$.

Special Collections copy: original paper boards, printed paper label on spine.

Bequest of Lane Cooper, Class of 1896. Lane Cooper was a professor English literature at Cornell University.

Facsimile of the manuscript of Milton's minor poems preserved in the library of Trinity college, Cambridge. Cambridge [England]: At the University Press, 1899.

[4], 7, [1] p., 47 leaves, 47 leaves of plates: facsims; $41 \mathrm{~cm}$.

Preface signed: William Aldis Wright. 
Acquired 1940 upon the advice of J. Milton French.

Paradise lost by John Milton, illustrations by William Blake. Liverpool: Printed at the Lyceum Press, Liverpool, and published by the Liverpool Booksellers' Co., Limited, 1906. ix, 397 p., [12] leaves of plates, color illustrations; $27 \mathrm{~cm}$.

"The text of this edition is that prepared by Dr. David Masson, for Messrs. MacMillan and Company ..."

Paradise regained / John Milton, decorated by Thomas Lowinsky.

London: The Fleuron, 1924.

[10], 80 p. illustrations; $23 \mathrm{~cm}$.

This edition is limited to 350 copies.

Issued with an extra set of Lowinsky's 3 illustrations, enclosed in an envelope and inserted in a pocket on the inside back cover.

Special Collections has copy no. 17.

Poems in English / John Milton, with illustrations by William Blake. 2 vols. London: The Nonesuch press, $1926.26 \mathrm{~cm}$.

Text edited by Canon Beeching. Pictures chosen and titled by Geoffrey Keynes.

"This edition, printed and made in England, consists of 1450 copies in two volumes on Van Gelder rag paper ... and 90 copies (the two volumes bound together) on Oxford India paper."

Special Collections has copy no. 124.

Paradise lost by John Milton, with the illustrations by William Blake printed in color for the first time, and with prefaces by Philip Hofer and John T. Winterich. New York: Heritage Press, c1940. xx, 311 p., [9] leaves of plates; color illustrations; $28 \mathrm{~cm}$.

L'allegro, Il penseroso / John Milton, with the paintings by William Blake. New York: Heritage Press, c1954. 43, [1], 44 p.; 26 cm.

L'allegro contains "A note upon the poems" by W.P. Trent. Il penseroso contains "A Note upon the paintings" by Chauncey Brewster Tinker.

Tête-bêche binding. 


\section{Notes}

1. J. Milton French, "Recent Acquisitions in English," The Journal of the Rutgers University Library 1, no. 4 (1940): 22.

2. Donald Cameron, "Gifts," The Journal of the Rutgers University Library 4, no. 2 (1941): no page number.

3. Donald A. Sinclair, "Gifts and Acquisitions," The Journal of the Rutgers University Library 17, no. 1 (1954): 26.

4. The library book plate stating that this edition was presented by Albert S. Cook may have been placed in error. This edition of Tetrachordon, the only one owned by the library, was among the books described by J. Milton French as acquired in 1940 (see note 1) - Cook died in 1927.

\section{References:}

Coleridge, K. A. A Descriptive Catalogue of the Milton Collection in the Alexander Turnbull Library, Wellington, New Zealand describing works printed before 1801 Held in the library at December 1975.

New York: Oxford University Press, 1980.

French, J. Milton. "Recent Acquisitions in English," The Journal of the Rutgers University Library 4, no. 1 (Dec. 1940): 22-25.

Gillett, Charles Ripley. Catalogue of the McAlpin Collection of British History and Theology. New York: [Union Theological Seminary], 1927-1930.

Madan, F. F. "Milton, Salmasius, and Dugard," The Library, ser. 4, v. 4 (1923): 119-145.

- _ - "A Revised Bibliography of Salmasius's Defensio Regia and Milton's Pro Populo Anglicano Defensio," The Library, ser. 5, v. 9 (1954): 101-121.

Shawcross, John T. Milton: A Bibliography for the Years 1624-1700. Binghamton, N.Y.: Medieval \& Renaissance Texts \& Studies, 1984.

Woodward, "The Athenian Society of Queen's College," Journal of the Rutgers University Library vol 3, no. 1 (1939): 13-19. 